\title{
Patient Safety Incident Differences Between Accredited and not Accredited Primary Health Center
}

\author{
Arlina Dewi*, Nevi Seftaviani**, Erna Rochmawati** \\ * M Author Correspondence: dewikoen@gmail.com \\ * Master of Hospital Administration, Universitas Muhammadiyah Yogyakarta, Indonesia \\ **Master of Hospital Administration, Universitas Muhammadiyah Yogyakarta, Indonesia
}

***Master of Nursing, Universitas Muhammadiyah Yogyakarta, Indonesia

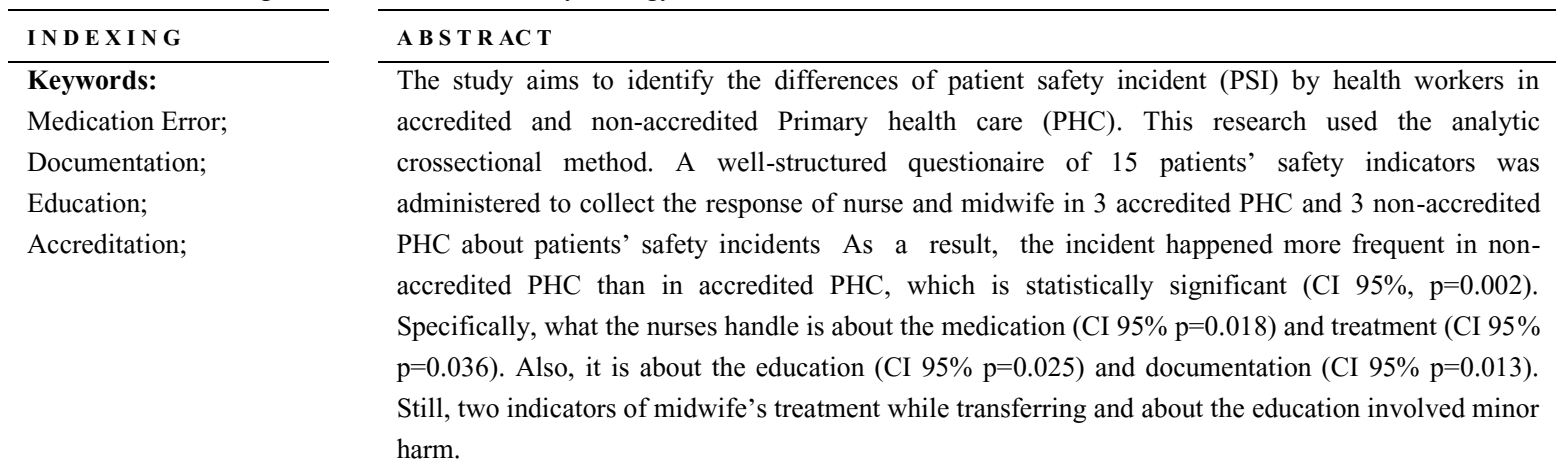

Kata kunci:

Kesalahan Pengobatan;

Dokumentasi;

Pendidikan;

Akreditasi;

\begin{abstract}
Penelitian ini bertujuan untuk mengidentifikasi perbedaan insiden keselamatan pasien (PSI) oleh petugas kesehatan dalam perawatan kesehatan primer (akreditasi) dan non-akreditasi. Penelitian ini menggunakan metode analitik crossectional. Sebuah kuesioner yang terstruktur dengan baik dari 15 indikator keselamatan pasien diberikan untuk mengumpulkan respon perawat dan bidan di 3 PHC terakreditasi dan 3 PHC non-terakreditasi tentang insiden keselamatan pasien. Akibatnya, insiden itu terjadi lebih sering di PHC non-terakreditasi daripada di PHC terakreditasi, yang signifikan secara statistik (CI 95\%, $p=0,002)$. Secara khusus, apa yang ditangani perawat adalah tentang obat (CI $95 \% p=0,018)$ dan pengobatan (CI 95\% $p=0,036)$. Juga, ini tentang pendidikan (CI 95\% $p=$ 0,025) dan dokumentasi (CI 95\% $p=0,013)$. Namun, dua indikator perawatan bidan saat mentransfer dan tentang pendidikan melibatkan kerusakan kecil.
\end{abstract}

(C) 2019 JMMR. All rights reserved

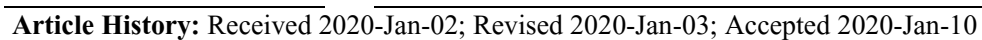

\section{INTRODUCTION}

In recent years, the number of patients' safety incident (PSI) increases in international area and Indonesia. In 1980-2014, on average, there were 2-3 PSI in 100 visits in Primary Health Care (PHC). ${ }^{1}$ Moreover, there is a minimum 1 PSI which happens daily in Primary Health Care (PHC) in Swiss. ${ }^{2}$ In UK, there are 2191 PCI in pediatric which make minor harm to death in $\mathrm{PHC}$ in 20052013. ${ }^{3}$ In Indonesia, the data of PSI on PHC are still rare and unclear, and those are still most available in hospital not in PHC. Besides, the example is taken from PSI report by Komite Keselamatan Rumah Sakit (KKPRS) in 2007 by province. Jakarta ranks highest (37.9\%) amongeight other provinces. They are Central Java (15.9\%), Yogyakarta (13.8\%), East Java (11,7\%), South Sumatera (6.9\%), West Java (2.8\%), Bali (1.4\%), Aceh (10.7\%), and South Sulawesi $(0.7 \%) .{ }^{4}$ In Yogyakarta itself, the data mostly get from hospital too. For example, in a hospital of Yogyakarta, there are 2 PSI about fall risk and near miss from January until June 2013. ${ }^{5}$

WHO responds these PSI issues by making a module of "The Technical Series on Safer Primary Care". It has happened because PHC becomes a soul of continuing care in society. Also, it can realize the aim of Sustainable Development Goals (SDG), which gives priority of health life and well-being life

promotion $(6,7)$. Indonesia starts paying attention to patients' safety in PHC by applying the BPJS system which utilizes the PHC more. In this case, it makes the PHC get more attention to patients' safety aspects too. Patients' safety in Indonesia is regulated in Permenkes number 11 the year 2017 regarding the patients' safety and in Permenkes number 75 the year 2014 about PHC. Then, this rule is inserted in PHC accreditation standard as an assessment standard of PHC (Kemenkes RI, 2015b, 2015a, 2017). 
Indonesia implemented PHC accreditation in the last 2015. The purpose of this accreditation is to increase the facility and quality of PHC service in human resources, equipment, infrastructure, and the legal aspect. In Yogyakarta, most of PHC have been accredited, and most of them are passed and certified as basic (dasar), middle (madya), primary (utama), or plenary (paripurna) level.

Patients' safety is specially regulated in chapter IX of accreditation standard (chapter of quality service and patients' safety).This standard refers to Hospital Patient Safety guidelines, so the PHC is required to have their own indicators about the patients' safety based on each PHC. This indicators should be evaluated, monitored, and followed-up based on the result. And regarding the fulfillment of the elements of PHC accreditation assessment, PHC will strive to maintain and continue the patients' safety event in PNC so the incident of patients' safety at the accredited PHC can decrease. But no research has indicated any influence of PHC accreditation in patient safety aspect, especially in PSI. Therefore, we sought to identify the differences between PSI in accredited and nonaccredited PHC.

According to Permenkes RI Number 11 the year 2017 about Patient safety, patient safety is a system which makes the patients safety. The system includes the risk assessment, identification, report, incident analysis, learning ability, follow-up the plans, and the solution implementation. ${ }^{8}$

Patients' safety was started in 1999 when the Institute of Medicine (IOM) broadcasts the report about "To Err is Human". Also, it influences international to reduce harm the patient, which is caused by health workers. ${ }^{9}$

Patients' safety target In Indonesia is based on WHO standard and Joint Commission International (JCI). Then it is applied as a rule in patients' safety and in PHC accreditation assessment standard. There are six targets, namely right patient identification, effective communication, high alert drug supervision, right location, right procedure, and right patient in the surgery. The following target is to reduce the risk of nosocomial infection, and reducing patient fall risk comes up as the last target.

PSI is an incident or the conditions that result or potential result in a preventable injury to the patient consists of harmful incident/adverse event (KTD), near miss (KNC), no harm (KTC), reportable circumstance (KPC), and sentinel. Harmful incident or adverse event is an incident which results in dangerous treatment to a patient. Nearmiss is an incident in which does not reach the patient. Not giving dangerous threatment to the patient is one of the ways which an event reached a patient without giving discernable harm resulted. Reportable circumstance is a situation which significant potential for harm is, but there is no incident occurred. Hence, sentinel is a harmful incident or adverse event which causes death or serious harm.

So any factor cause PSI. According to Carayon et al., who used work system model, a person can be a care provider, another employee of a healthcare institution such as a biomedical engineer, a unit clerk, or the patient performs a range of tasks using various tools and technologies. The performance of these tasks occurs within a certain physical environment and under specific organizational conditions. The five components of work system (person, tasks, tools and technologies, physical environment, organizational conditions) interact and influence one another. The interactions among the various components produce different outcomes such as performance, safety and health, and quality of working life. Besides, a study conducted by Rees et al. and Singh et al. contributes in Primary care in UK, and the factors contributed to PSI are staff factor, organization factor, patient factor, equipment, and drug factor, and environment factor.

PHC accreditation in Indonesia is regulated by Permenkes RI number 46 the year 2015, which mentioned that accreditation is the acknowledgment given by the independent accreditation organizers stipulated by the Minister after meeting the Accreditation standards. ${ }^{12}$

This accreditation program was prepared since 2014, but it was just started in 2015. This program will be held gradually, and in 2019, all health centers in the region of Indonesia have been accredited. Puskesmas will be categorized into accredited plenary (paripurna), accredited primarily (utama), accredited medium (madya), accredited basis (dasar), or not accredited based on accreditation assessment. The accreditation aims are to improve the service of quality and patients' safety. Also, it is to improve the protection of human resources health, society and environment, and Puskesmas, and to improve the performance of PHC during giving health service. In accreditation assessment standard, patients' safety is regulated in chapter IX which assesses the responsibility of health workers, comprehension of quality service, assessment of quality service and patient safety target, and improvement of quality service and patient safety. 
The relation between accreditation and patient safety has been discussed but in hospital, not PHC. According to ${ }^{13}$ and ${ }^{14}$, hospital accreditation influences the patients' safety culture and nurse's report. After processing of accreditation, nurse can identify the patients' safety and is aware of reporting PSI. However, ${ }^{2}$ has been asses the PSI indicator in PHC in Germany. Still, he did not mind about the accreditation status.

\section{RESEARCH METHOD}

This research has been conducted in 3 primarily (utama) accredited PHC and 3 non-accredited PHC in a district of Yogyakarta for two months from September 2017 until November 2017. The method is an analytical crossectional quantitative design. The population in this study is nurse and midwife in those PHC.

The total sampling method got 89 nurses and midwives, specifically 45 nurses and midwives in accredited PHC, while in non-accredited PHC was 44 nurses and midwives who met the inclusion and exclusion criteria. The inclusion criteria were the nurse and the midwife who agreed to be the respondents and submitted the questionnaire on time. Accordingly, the exclusion criteria were the nurse and midwife who had in periods of leave, sick or undertaking further studies when the research was ongoing.

Tools and materials used in this research are the informed consent form and a questionnaire about patient safety incident. The questionnaire consists of 15 PSI indicators and was taken and modified from previous research by ${ }^{2,3,15}$. This questionaire asked the respondents to recall the PSI frequencies which they had done in last month. Also, it recalled the memory of respondents about severity of harm which arised from PSI by "no harm", "minor (minimal) harm", "moderate", "severe", or "death".

The questionnaire was directly given to the respondent and the researcher gave the respondent one week to fill the questionairre. It was intended to make the respondent have more time in recall and filling the questionairre. But, the respondent was guided and accompanied by the researcher before fill the questionairre. Then, non parametric independent-t-test was used to identify the differences of PSI in accredited PHC and nonaccredited PHC. After the test got result, it could be identified the differences of patient safety incident between accredited and non-accredited PHC based on it's frequency and it's severity of harm.

\section{RESULTS AND DISCUSSION}

\section{Characteristic}

This research used 89 nurses and midwives as the repondents from 3 accredited PHC and 3 non-accredited PHC. The table 1 shows that most of the respondents are midwives, womenboth in accredited and non-accredited PHC.. Both of PHC do not have the workers in the age of more than 58 years old. This is appropriate with the provisions of retirement age, which is 58 years old. Based on participation in patient safety training, most of respondents never follow the training.

Table 1. Respondent Characteristics by Profession, Age, Gender, Year of proffesional experience, Years of work in this office, and Participation in patient safety training

\begin{tabular}{|c|c|c|c|}
\hline \multirow{2}{*}{ No } & \multirow{2}{*}{ Characteristic } & \multicolumn{2}{|c|}{ Number (\%) } \\
\hline & & Accredited PHC & Non Accredited PHC \\
\hline \multirow[t]{3}{*}{1} & Profession & & \\
\hline & Nurse & $18(40)$ & $18(20)$ \\
\hline & Midwife & $27(60)$ & $26(60)$ \\
\hline \multirow[t]{3}{*}{2} & Gender & & \\
\hline & Male & $4(9)$ & $6(5)$ \\
\hline & Female & $41(91)$ & $57(95)$ \\
\hline \multirow[t]{5}{*}{3} & Age & & \\
\hline & $<31$ y.o. & $7(16)$ & $4(9)$ \\
\hline & $31-50$ у.о. & $35(78)$ & $28(63)$ \\
\hline & 51-58 у.о. & $3(6)$ & $12(27)$ \\
\hline & $>58$ y.o. & $0(0)$ & $0(0)$ \\
\hline
\end{tabular}




\begin{tabular}{|c|c|c|c|}
\hline \multirow{2}{*}{ No } & \multirow{2}{*}{ Characteristic } & \multicolumn{2}{|c|}{ Number (\%) } \\
\hline & & Accredited PHC & Non Accredited PHC \\
\hline \multirow[t]{4}{*}{4} & Year of proffesional experience & & \\
\hline & $1-5$ years & $4(9)$ & $1(2)$ \\
\hline & $5-10$ years & $18(40)$ & $23(52)$ \\
\hline & $>10$ years & $23(50)$ & $20(46)$ \\
\hline \multirow[t]{4}{*}{5} & Years of work in this office & & \\
\hline & $1-5$ years & $4(9)$ & $4(9)$ \\
\hline & $5-10$ years & $22(49)$ & $27(61)$ \\
\hline & $>10$ years & $19(42)$ & $13(30)$ \\
\hline \multirow[t]{3}{*}{6} & Participation in patient safety training & & \\
\hline & Yes & $15(33)$ & $1(2)$ \\
\hline & No & $30(67)$ & $43(98)$ \\
\hline \multicolumn{2}{|c|}{ Total } & $45(100)$ & $44(100)$ \\
\hline
\end{tabular}

\section{PSI Frequency}

This study aims to identify the differences of PSI in accredited PHC and non-accredited PHC by identified the frequency and severity of harm in nurse and midwife in the last month. This discussion focused on the patients' safety indicator which had more frequency or only happened in accredited PHC and indicator, which effect severity of harm in patient.

Table 2 shows that overall PSI in both nurse and midwife is more frequent in non-accredited than accredited PHC. It is supported by the different aspect which is statistically significant $(\mathrm{p}=0.002)$.

Table 2. Frequency of PSI in Accredited and non-Accredited PHC in August 2017 by Nurse and Midwife

\begin{tabular}{llccc}
\hline No & Profession & Frequency & PSI \\
& & Accredited PHC & Non-Accredited PHC & CI 95\% \\
\hline 1 & Nurse & 47 & 35 & 0.335 \\
2 & Midwife & 49 & 19 & 0.002 \\
& Total & 96 & 55 & 0.002 \\
\hline
\end{tabular}

This differences were caused by the accredited PHC had assesed during proccess of accreditation especially in Chapter Quality Service and Patients' Safety which consists of clinical staff's responsibilities, understanding, measurement, and quality improvement on clinical services and patient safety. Those made health workers, nurse and midwife in accredited PHC knew more about quality service and patient safety. Besides, the result was in line with Elnour et al. who said that in Australia, the accreditation program had improved the quality service and patient safety, especially in PSI reporting and regular meeting to discuss about PSI prevention. ${ }^{17}$ also explained that hospital accreditation status in Bangladesh statistically significant with patient satisfaction on hospital infrastructure, equipment, information, education, and communication because accreditation had reached both in clinical and non-clinical process and outcome. It can be concluded that in development country, accreditation becomes one improvement factor in quality of service.

Specifically, figure 1 and table 3 shows the PSI in nurse and midwife. Three top rank indicators in nonaccredited PHC by nurse is Q14 (Information from external provider is missing, incomplete, or errant when required), Q13 (Relevant message or notice relayed, left, or passed incomplete, wrong, incorrect, or unclear), and Q3 (Required medication not prescribed, administered, or dispensed). Besides, midwifes are Q13 (Relevant message or notice relayed, left, or passed incomplete, wrong, incorrect, or unclear), Q14 (Information from external provider is missing, incomplete, or errant when required), and Q8 (Failure to perform a properly ordered therapeutic intervention while transferring the patient). 
In Accredited PHC, three top rank indicators through nurse are Q13 (Relevant message or notice relayed, left, or passed incomplete, wrong, incorrect, or unclear), Q14 (Information from external provider is missing, incomplete, or errant when required), and Q12 (Failure to educate

Frequency of Patient Safety Incident (PSI) in Accredited and Non-Accredited Primary Health Care (PHC)

by Nurse and Midwife in Last Month

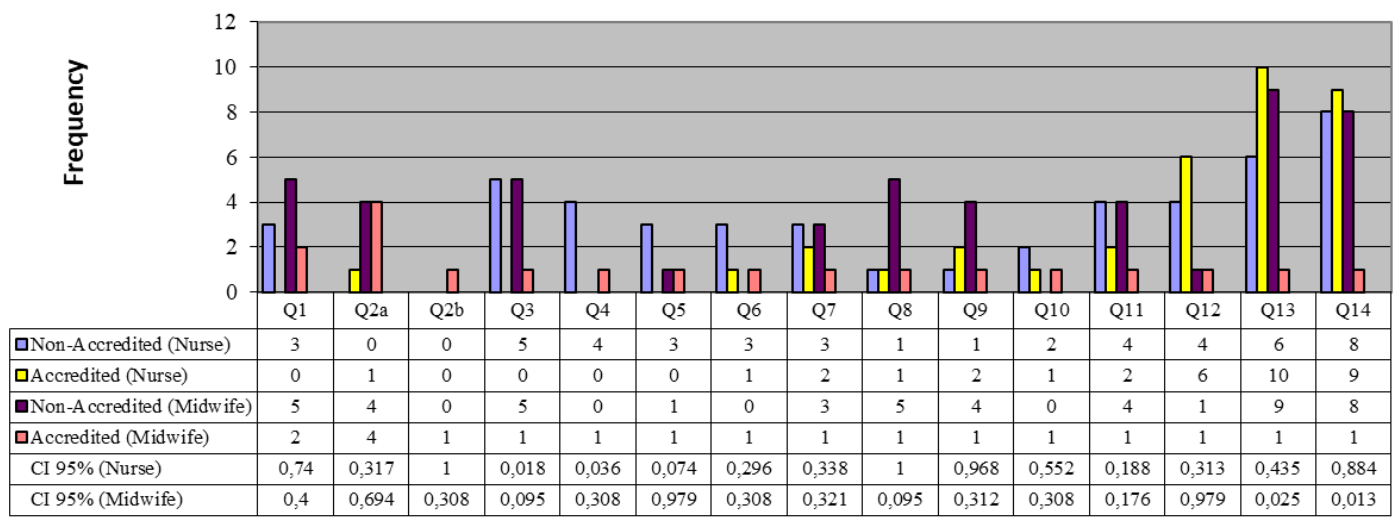

Indicator

$\square$ Non-Accredited (Nurse) $\quad \square$ Accredited (Nurse) $\quad \square$ Non-Accredited(Midwife) $\quad \square$ Accredited (Midwife)

Figure 1. Frequency of PSI in Accredited PHC and Non-Accredited PHC by Nurse and Midwife in last month

Patient about use of medication when administering or dispensing drugs). While by midwife are Q2a (Errant or incorrect prescription, administration, or dispensing of medication: wrong agent or wrong route or wrong dose/amount or wrong timing) and Q1 (Indicated test or examination not performed or performed at the wrong time).

Table 3. Indicators of PSI by nurse and midwife

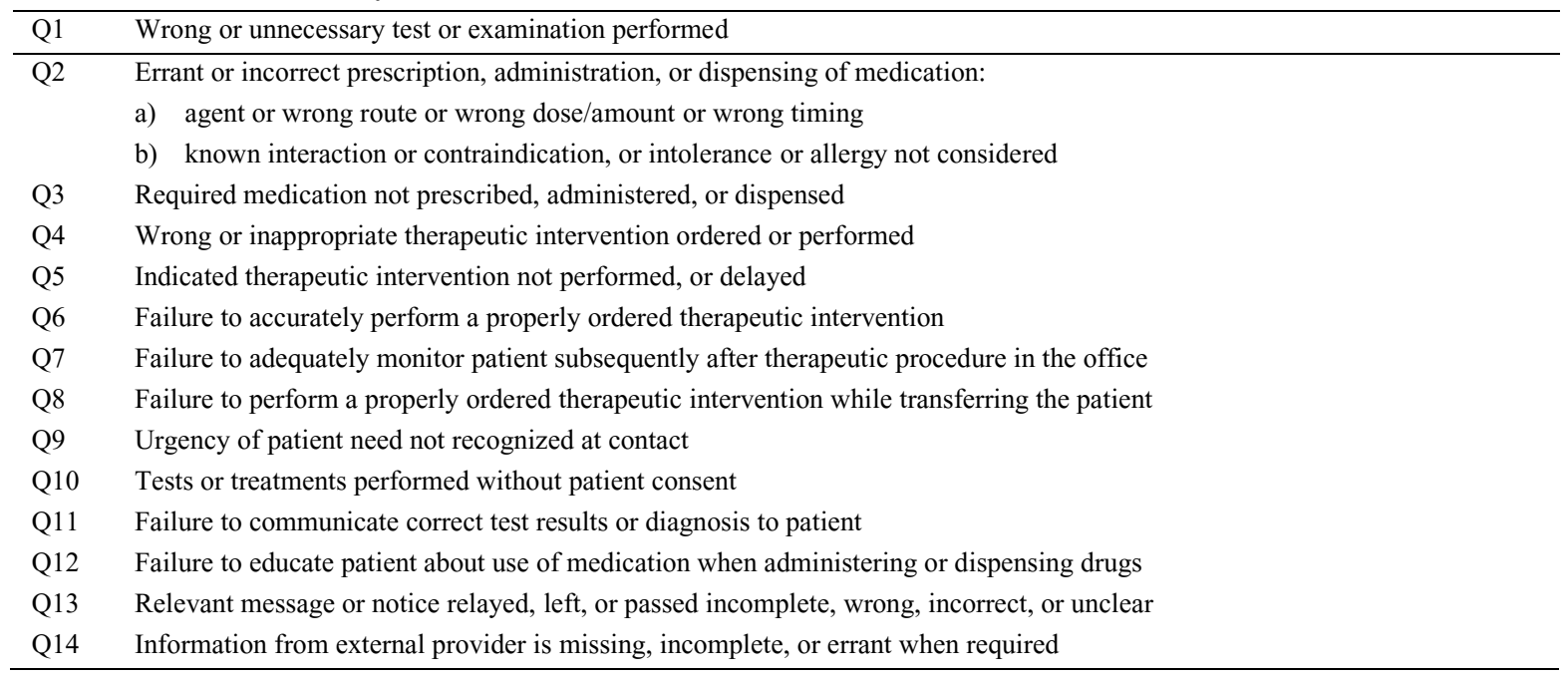

The figure 1 also shows that most of the indicator has the higher frequency in non-accredited PHC than accredited PHC. However figure 1 also shows about the indicator which has higher frequency in acrredited PHC, but it is not statistically significant. Those indicators are Q2a (Errant or incorrect prescription, administration, or dispensing of medication: wrong agent or wrong route or wrong dose/amount or wrong timing), Q9 (Urgency of 
patient need not recognize at contact), Q12 (Failure to educate patient about use of medication when administering or dispensing drugs), and Q14 (Information from external provider is missing, incomplete, or errant when required) by nurse. Thus, midwife is Q2b (Errant or incorrect prescription, administration, or dispensing of medication known as interaction or contraindication, or intolerance or allergy not considered) and Q6 (Failure to accurately perform a properly ordered therapeutic intervention).

Those summarization is about diagnosis, medication/treatment, communication, and documentation. Even though, it was contardictory with PHC accreditation assesment in chapter 9.3.1 about Measurement which had to use effective instruments to assess quality of service and patient safety target. On that chapter, in number 3, there was criteria of quality service assesment including patient's assesment aspect, diagnosis support service, use of antibiotic, and nosocomial infection control. ${ }^{18}$ Those criteria should be a standard to prevent PSI on PHC. But, that criteria as the government policy factor is not the only one factor which influences PSI. According on Rees et al. and Singh et al. , the factors that influence PSI in UK PHC come from staff factor, organization factor, patient factor, drug and equipment factor, and environment factor. Moreover, Carayon et al. explained that most of errors and inaccuracies appear not form individues, but it comes from conflict, incomplete system, or less optimal system in work place. Lawton et al. also mentioned that there are 18 factors which influence PSI in hospital, and those are communication, equipment availibility, government policies, design of equipment, individu factor, management, patient factor, workplace environment, patient safety culture, schedule, work time, supervision, support from government, work characteristic, team factor, and the last is education and training factor.

One factor about government policies was explained by Mohebbifar et al. (2017) who stated that in Bangladesh there was no consistency between accreditation standard and patient medical needs, so it needs evaluation which can fulfill the patient's need. In this case, it occurs about communication. Health worker knowledge as another factor was explained by ${ }^{20}$ that in one of Hospital in North Sulawesi healthworker knowledge was statistically significant with patient safety implementation. Higher knowledge health worker made more active in patient safety implementation. In this research, the respondents in accredited PHC had more frequency on those indicators because they had more knowledge about patient safety from pra and pasca accreditation training. Pra accreditation training is one of accreditation process series to make the PHC ready for the accreditation assesment. Besides, pasca accreditation accompaniment is an event to maintain and improve the standard accreditation achievement until the next accreditation assesment. Those apects mentioned previously, could make health worker in accredited PHC more understandable to the patient safety, so they could identify potential incident before the real PSI.

\section{Severity of Harm}

Severity of harm in this study is divided into no harm, minor, moderate, severe, and death. However, the data result in table 4 shows that the severity harm which happened is only no harm and minor harm. There is no indicator which shows moderate, severe, or death. Also, the minor harm only happened by midwife in non-accreditation PHC. Those indicators are Q8 (Failure to perform a properly ordered therapeutic intervention while transferring the patient)) and Q13 (Relevant message or notice relayed, left, or passed incomplete, wrong, incorrect, or unclear).

In this study, there were 2 indicators of midwife in non-accredited PHC which influence minor harm in patient. Thos indicators were about educating the patient and giving treatment while transfering the patient. Those factors did contribute to harm even death in patient, and in this midwifery, it was neonatal and maternal death.

According to ${ }^{21}$, transferral procces in Sidoharjo district of East Java affected the maternal death. Besides, the midwife should educate the productive woman age, improve the family role, people, and health cares to detect the complication during pregnancy, labour, post-partum, improve the quality of Ante Natal Care (ANC), and improve the transferral quality by using closed tranferral system in the maternal area who has high risk can be followed-up.

In addition, according to ${ }^{22}$, in Bantul district there was fact that human resources availibility, equipment, and drug were not appropriate with Basic Emergency Neonatal Obstetric Services (PONED) and Comprehensive Emergency Neonatal Obstetric Services (PONEK). Moreover, referral communicatin levels was not ideal. The implementation of health insurance did make the late medical claimed service while the government supervision is not optimal. 
Table 4. PSI Severity of Harm by Nurse and Midwife in Accredited and Non-Accredited PHC in August 2017

\begin{tabular}{|c|c|c|c|c|c|}
\hline \multirow[b]{2}{*}{ No } & \multirow[b]{2}{*}{ Indicator } & \multicolumn{2}{|c|}{ Nurse } & \multicolumn{2}{|c|}{ Midwife } \\
\hline & & Non-accredited & Accredited & $\begin{array}{l}\text { Non- } \\
\text { accredited }\end{array}$ & Accredited \\
\hline Q1 & $\begin{array}{l}\text { Wrong or unnecessary test or examination } \\
\text { performed }\end{array}$ & $100 \%$ No Harm & - & $\begin{array}{l}100 \% \text { No } \\
\text { Harm }\end{array}$ & $\begin{array}{l}100 \% \text { No } \\
\text { Harm }\end{array}$ \\
\hline Q2 & $\begin{array}{l}\text { Errant or incorrect prescription, administration, or } \\
\text { dispensing of medication: } \\
\text { a. agent or wrong route or wrong dose/amount } \\
\text { or wrong timing } \\
\text { b. known interaction or contraindication, or } \\
\text { intolerance or allergy not considered }\end{array}$ & $\begin{array}{l}- \\
-\end{array}$ & $\begin{array}{l}100 \% \text { No } \\
\text { Harm } \\
-\end{array}$ & $\begin{array}{l}100 \% \text { No } \\
\text { Harm } \\
-\end{array}$ & $\begin{array}{l}100 \% \text { No } \\
\text { Harm } \\
-\end{array}$ \\
\hline Q3 & $\begin{array}{l}\text { Required medication not prescribed, administered, } \\
\text { or dispensed }\end{array}$ & $100 \%$ No Harm & - & $\begin{array}{l}100 \% \text { No } \\
\text { Harm }\end{array}$ & $\begin{array}{l}100 \% \text { No } \\
\text { Harm }\end{array}$ \\
\hline Q4 & $\begin{array}{l}\text { Wrong or inappropriate therapeutic intervention } \\
\text { ordered or performed }\end{array}$ & $100 \%$ No Harm & - & - & $\begin{array}{l}100 \% \text { No } \\
\text { Harm }\end{array}$ \\
\hline Q5 & $\begin{array}{l}\text { Indicated therapeutic intervention not performed, or } \\
\text { delayed }\end{array}$ & $100 \%$ No Harm & - & 100\% Minor & $\begin{array}{l}100 \% \text { No } \\
\text { Harm }\end{array}$ \\
\hline Q6 & $\begin{array}{l}\text { Failure to accurately perform a properly ordered } \\
\text { therapeutic intervention }\end{array}$ & $100 \%$ No Harm & $\begin{array}{l}100 \% \text { No } \\
\text { Harm }\end{array}$ & - & $\begin{array}{l}100 \% \text { No } \\
\text { Harm }\end{array}$ \\
\hline Q7 & $\begin{array}{l}\text { Failure to adequately monitor patient subsequently } \\
\text { after therapeutic procedure in the office }\end{array}$ & $100 \%$ No Harm & $\begin{array}{l}100 \% \text { No } \\
\text { Harm }\end{array}$ & $\begin{array}{l}100 \% \text { No } \\
\text { Harm }\end{array}$ & $\begin{array}{l}100 \% \text { No } \\
\text { Harm }\end{array}$ \\
\hline Q8 & $\begin{array}{l}\text { Failure to perform a properly ordered therapeutic } \\
\text { intervention while transferring the patient }\end{array}$ & $100 \%$ No Harm & $\begin{array}{l}100 \% \text { No } \\
\text { Harm }\end{array}$ & $\begin{array}{l}50 \% \text { No } \\
\text { Harm } \\
50 \% \text { Minor }\end{array}$ & $\begin{array}{l}100 \% \text { No } \\
\text { Harm }\end{array}$ \\
\hline Q9 & Urgency of patient need not recognized at contact & $100 \%$ No Harm & $\begin{array}{l}100 \% \text { No } \\
\text { Harm }\end{array}$ & $\begin{array}{l}100 \% \text { No } \\
\text { Harm }\end{array}$ & $\begin{array}{l}100 \% \text { No } \\
\text { Harm }\end{array}$ \\
\hline Q10 & $\begin{array}{l}\text { Tests or treatments performed without patient } \\
\text { consent }\end{array}$ & $100 \%$ No Harm & $\begin{array}{l}100 \% \text { No } \\
\text { Harm }\end{array}$ & - & $\begin{array}{l}100 \% \text { No } \\
\text { Harm }\end{array}$ \\
\hline Q11 & $\begin{array}{l}\text { Failure to communicate correct test results or } \\
\text { diagnosis to patient }\end{array}$ & $100 \%$ No Harm & $\begin{array}{l}100 \% \text { No } \\
\text { Harm }\end{array}$ & $\begin{array}{l}100 \% \text { No } \\
\text { Harm }\end{array}$ & $\begin{array}{l}100 \% \text { No } \\
\text { Harm }\end{array}$ \\
\hline Q12 & $\begin{array}{l}\text { Failure to educate patient about use of medication } \\
\text { when administering or dispensing drugs }\end{array}$ & $100 \%$ No Harm & $\begin{array}{l}100 \% \text { No } \\
\text { Harm }\end{array}$ & $\begin{array}{l}100 \% \text { No } \\
\text { Harm }\end{array}$ & $\begin{array}{l}100 \% \text { No } \\
\text { Harm }\end{array}$ \\
\hline Q13 & $\begin{array}{l}\text { Relevant message or notice relayed, left, or passed } \\
\text { incomplete, wrong, incorrect, or unclear }\end{array}$ & $100 \%$ No Harm & $\begin{array}{l}100 \% \text { No } \\
\text { Harm }\end{array}$ & $\begin{array}{l}67 \% \text { No } \\
\text { Harm } \\
33 \% \text { Minor }\end{array}$ & $\begin{array}{l}100 \% \text { No } \\
\text { Harm }\end{array}$ \\
\hline Q14 & $\begin{array}{l}\text { Information from external provider is missing, } \\
\text { incomplete, or errant when required }\end{array}$ & $100 \%$ No Harm & $\begin{array}{l}100 \% \text { No } \\
\text { Harm }\end{array}$ & $\begin{array}{l}100 \% \text { No } \\
\text { Harm }\end{array}$ & $\begin{array}{l}100 \% \text { No } \\
\text { Harm }\end{array}$ \\
\hline
\end{tabular}

Educating the patient or communication aspect still becomes one of reported medical error, near miss, or potential factor. ${ }^{23}$ This is also in line with ${ }^{24}$ in $1949-2008$ who stated that health worker communication is statistically significant wtih patient adherence. Additionally, ${ }^{24}$ explained that there was $19 \%$ higher risk of patient nonadherence in health worker who had less communication with their patient. It is also supported by ${ }^{25}$ that communication becomes one determinant factor of patient satisfaction as a service user, and it is also communication as one of the indicators in the assessment of service quality in health service. Satisfied patients will deal with the advice, loyal and adherence the treatment plan. Moreover ${ }^{26}$ showed that adherence patients give bigger influence in patient's health. Consequently, those studies showed that communication aspect between health worker and patient become one important factor in making better or worse the patient condition.

Besides in minor harm, another no harm indicator should be aware too. This causes no harm indicators that may be potential to be another PSI, as near miss, accordance with the definiton in Permenkes RI number 11 year 2017 about Patient safety. ${ }^{8}$ Therefore, it needs 
attention from health worker, PHC managerial, and even from government in controling and reducing PSI in PHC.

\section{CONCLUSION}

This study showed that the accreditation process could reduce the PSI frequency and severity of harm in PHC which is proved by the higher frequency of PSI in non-accredited PHC than in accredited PHC. Besides that, PSI indicator in non-accredited PHC involved minor harm. That is because the accredited PHC had assessed during the process of accreditation, especially in Chapter Quality Service and Patients' Safety, which consists of clinical staff's responsibilities, understanding, measurement, and quality improvement on clinical services and patient safety. Those made health workers, nurse and midwife in accredited PHC knew more about quality service and patient safety. However, a regular meeting should be routinely performed to evaluate the PSI and also refreshing training about patient safety in diagnosis, therapy, communication, documentation, and professional ethics should be conducted, too. However, this study can not identify the specific incident form and the right factor which influences the PSI. That way, in further study, it should not only do the quantitative study, but also qualitative study by doing a deep interview with the respondents.

\section{REFERENCE}

1. Panesar SS, deSilva D, Carson-Stevens A, Cresswell KM, Salvilla SA, Slight SP, et al. How safe is primary care? A systematic review. BMJ Qual Saf. 2016 Jul;25(7):544-53.

2. Gehring K, Schwappach DLB, Battaglia M, Buff R, Huber F, Sauter P, et al. Frequency of and Harm Associated With Primary Care Safety Incidents. Am J Manag Care. 2012;18(9):e323-37.

3. Rees P, Edwards A, Powell C, Hibbert P, Williams H, Makeham M, et al. Patient safety incidents involving sick children in primary care in England and Wales: a mixed methods analysis. PLoS Med. 2017;14(1):e1002217.

4. Keles AW. Analisis Pelaksanaan Standar Sasaran Keselamatan Pasien di Unit Gawat Darurat RSUD Dr. Sam Ratulangi Tondano Sesuai dengan Akreditasi Rumah Sakit Versi 2012. JIKMU. 2015;5(3).

5. Fatimah FS, Rosa EM. Efektivitas Pelatihan Patient Safety; Komunikasi S-BAR pada Perawat dalam Menurunkan Kesalahan Pemberian Obat Injeksi di Rumah Sakit PKU Muhammadiyah Yogyakarta Unit II.
J Ners Dan Kebidanan Indones. 2016;2(1):32-41.

6. Simmonds FD, Alexander TL. Vital signs 2015: The state of safety and quality in Australian health care. 2015;

7. WHO. Patient safety: making health care safer. 2017;

8. Kemenkes RI. Permenkes RI Nomor 11 Tahun 2017 tentang Keselamatan Pasien. Kementerian Kesehatan Republik Indonesia; 2017.

9. Kohn LT, Corrigan J, Donaldson MS, editors. To err is human: building a safer health system. Washington, D.C: National Academy Press; 2000. 287 p.

10. Carayon P, Schoofs Hundt A, Karsh B-T, Gurses AP, Alvarado CJ, Smith M, et al. Work system design for patient safety: the SEIPS model. Qual Saf Health Care. 2006 Dec 1;15(suppl_1):i50-8.

11. Singh H, Giardina TD, Meyer AND, Forjuoh SN, Reis MD, Thomas EJ. Types and Origins of Diagnostic Errors in Primary Care Settings. JAMA Intern Med. 2013 Mar 25;173(6):418.

12. Kemenkes RI. Permenkes RI Nomor 46 tahun 2015 tentang Akreditasi Puskesmas, Klinik Pratama, Tempat Praktik Mandiri Dokter dan Dokter Gigi [Internet]. 2015 [cited 2018 Feb 22]. Available from: http://yankes.kemkes.go.id/assets/downloads/PMK\%20 No.\%2046\%20\%20ttg\%20Akreditasi\%20Puskesmas, \% 20Klinik\%20\%20Pratama,\%20Tempat\%20Praktik\%20 Mandiri\%20Dokter\%20dan\%20Dokter\%20Gigi.pdf

13. Lee E. Safety climate and attitude toward medication error reporting after hospital accreditation in South Korea. Int J Qual Health Care. 2016 Sep;28(4):508-14.

14. Wijaya AS, Dewi A. Analisis Budaya Keselamatan Pasien Di RSU PKU Muhammadiyah, Bantul. JMMR J Medicoeticolegal Dan Manaj Rumah Sakit. 2015;4(1).

15. Rees P, Edwards A, Powell C, Evans HP, Carter B, Hibbert $\mathrm{P}$, et al. Pediatric immunization-related safety incidents in primary care: A mixed methods analysis of a national database. Vaccine. 2015 Jul;33(32):3873-80.

16. Elnour AA, Hernan AL, Ford D, Clark S, Fuller J, Johnson JK, et al. Surveyors' perceptions of the impact of accreditation on patient safety in general practice. Med J Aus. 2014;201(3):556-9.

17. Mohebbifar R, Rafiei S, Asl AM, Ranjbar M, Khodayvandi M. Association between Hospital Accreditation and Patient Satisfaction: A Survey in the Western Province of Iran. Bangladesh J Med Sci. 2017;16(1):77.

18. Kemenkes RI. Instrumen Akreditasi Puskesmas. Kementerian Kesehatan Republik Indonesia; 2015.

19. Lawton R, McEachan RRC, Giles SJ, Sirriyeh R, Watt 
IS, Wright J. Development of an evidence-based framework of factors contributing to patient safety incidents in hospital settings: a systematic review. BMJ Qual Saf. 2012 May;21(5):369-80.

20. Bawelle SC, Sinolungan JSV, Hamel R. Hubungan pengetahuan dan sikap perawat dengan pelaksanaaan keselamatan pasien (patient safety) di ruang rawat inap RSUD Liun Kendage Tahuna. E-J Keperawatan. 2013;1:4-6.

21. Handriani I, Melaniani S. The Effect of Referral Process and Complications to Maternal Mortality. J Berk Epidemiol. 2015;3(3):400-411.

22. Trisnantoro L, Komala I. Evaluasi Pelaksanaan Rujukan Maternal Dan Neonatal Di Kabupaten Bantul [Phd Thesis]. Universitas Gadjah Mada; 2015.

23. Smith K, Baker K, Wesley D. Guide to Improving Patient Safety in Primary Care Settings by Engaging Patients and Families: Environmental Scan Report [Internet]. Agency for Healthcare Research and
Quality; 2017. Available from: https://www.ahrq.gov/professionals/quality-patientsafety/patient-

familyengagement/pfeprimarycare/envscan/index.html.

24. Haskard Zolnierek KB, DiMatteo MR. Physician Communication and Patient Adherence to Treatment: A Meta-Analysis. Med Care. 2009 Aug;47(8):826-34.

25. Firdaus FF, Dewi A. Evaluasi Kualitas Pelayanan Terhadap Kepuasan Pasien Rawat Jalan Peserta Bpjs Di Rsud Panembahan Senopati Bantul. JMMR J Medicoeticolegal Dan Manaj Rumah Sakit [Internet]. 2015 Jul 1 [cited 2018 Feb 19];4(2). Available from: http://journal.umy.ac.id/index.php/mrs/article/view/690

26. Marie BT, Sinsky C. Medication Adherence : Improve the health of your patients and reduce overall health care costs. Am Med Assoc. 2015; 